In-Line Fuzing Development for Tactical Airfield Attack Munition (TAAM)

J. J. Morrison

March 18, 1981

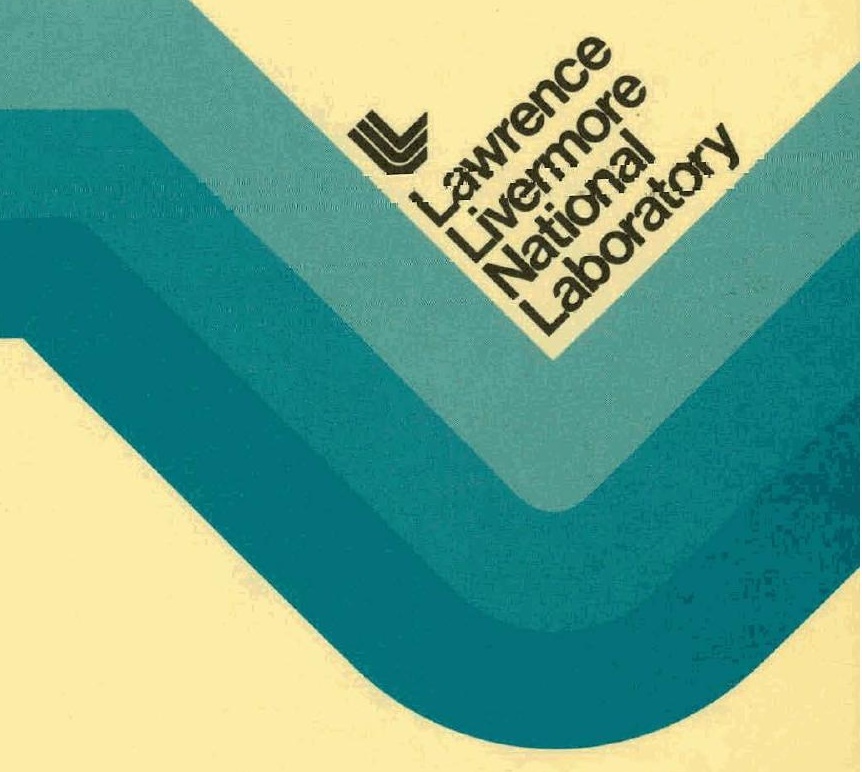




\section{DISCLAIMER}

This report was prepared as an account of work sponsored by an agency of the United States Government. Neither the United States Government nor any agency Thereof, nor any of their employees, makes any warranty, express or implied, or assumes any legal liability or responsibility for the accuracy, completeness, or usefulness of any information, apparatus, product, or process disclosed, or represents that its use would not infringe privately owned rights. Reference herein to any specific commercial product, process, or service by trade name, trademark, manufacturer, or otherwise does not necessarily constitute or imply its endorsement, recommendation, or favoring by the United States Government or any agency thereof. The views and opinions of authors expressed herein do not necessarily state or reflect those of the United States Government or any agency thereof. 


\section{DISCLAIMER}

Portions of this document may be illegible in electronic image products. Images are produced from the best available original document. 


\section{DISCLAIMER}

This document was prepared as an account of work sponsored by an agency of the United States Government. Neither the United States Government nor the University of California nor any of their employees, makes any warranty, express or implied, or assumes any legal liability or responsibility for the accuracy, completeness, or usefulness of any information, apparatus, product, or process disclosed, or represents that its use would not infringe privately owned rights. Reference herein to any specific commercial products, process, or service by trade name, trademark, manufacturer, or otherwise, does not necessarily constitute or imply its endorsement, recommendation, or favoring by the United States Government or the University of California. The views and opinions of authors expressed herein do not necessarily state or reflect those of the United States Government thereof, and shall not be used for advertising or product endorsement purposes.

Work performed under the auspices of the U.S. Department of Energy by Lawrence Livermore National Laboratory under Contract W-7405-Eng-48. 
UCRL-53180

Distribution Category UC-13

\title{
In-Line Fuzing Development for Tactical Airfield Attack Munition (TAAM)
}

\author{
J. J. Morrison
}

Manuscript date: March 18, 1981

LAWRENCE LIVERMORE LABORATORY University of California $\bullet$ Livermore, California 94550 


\author{
IN-LINE FUZING DEVELOPMENT \\ FOR \\ TACTICAL AIRFIELD ATTACK MUNITION (TAAM)
}

ABSTRACT

The shock-hardened new-concept safing, arming, and in-line fuzing system developed for U.S. Air Force modular weapons is being advanced for the Tactical Airfield Attack Munition (TAAM) as an alternate fuzing system. The high power slapper detonator system is being reduced in volume by an approximate factor of 10 and the energy by a factor of 3. In addition, the fuze has the capability of functioning after many hours of delay to provide area-denial capabilities.

\title{
DESCRIPTION AND OPERATIONAL SEQUENCE
}

The in-line fuzing system uses state-of-the-art, insensitive, high-peak-power, slapper detonators that can be used in-line with the main-charge explosives, and meets the requirements of Military standard 1316. In addition, the in-line system provides the capability to provide a long delay function for the Follow Through (FT) fuze. This long delay provides a buried mine capability, with the FT charge being buried below the runway surface. The slapper detonator Safing Arming and Fuzing (SAF) system is shown in Fig. 1. The arming module, located in the cruise missile, is microcomputer based which controls the arming of the Forward Charge (FC) and Velocity Augmentor(VA) fireset, the Follow Through (FT) fireset, and also initializes the parachute timer. The arming module encodes and transmits data to each of the 58 submunitions on board the MRASM. Each submunition must receive three commands: first, the FT fuze delay, short ( $45 \mathrm{~ms}$ ) or long ( $30 \mathrm{~min}$ to $8 \mathrm{hr}$ ); second, a series of unique signal commands to operate the $5-\mathrm{kV}$ dc-to-dc converter; and third, a parachute timer start command. A single slapper detonator fireset is used to ignite the FC and VA through a Mild Detonating Fuze (MDF) train. The FC fireset consists of a $0.2-\mu F$ capacitor, a high voltage crush switch and a 5-kv dc-to-dc converter. The arming module charges the capacitor to $5 \mathrm{kV}$ using a unique signal, repeated many times.

The high voltage crush switch transfers the energy $(2.5 \mathrm{~J})$ stored in.the $0.2-\mu \mathrm{F}$ capacitor to the slapper detonator, igniting an LX-15 pellet and the MDF train. The mechanical configuration of the in-line sAF system is shown in 


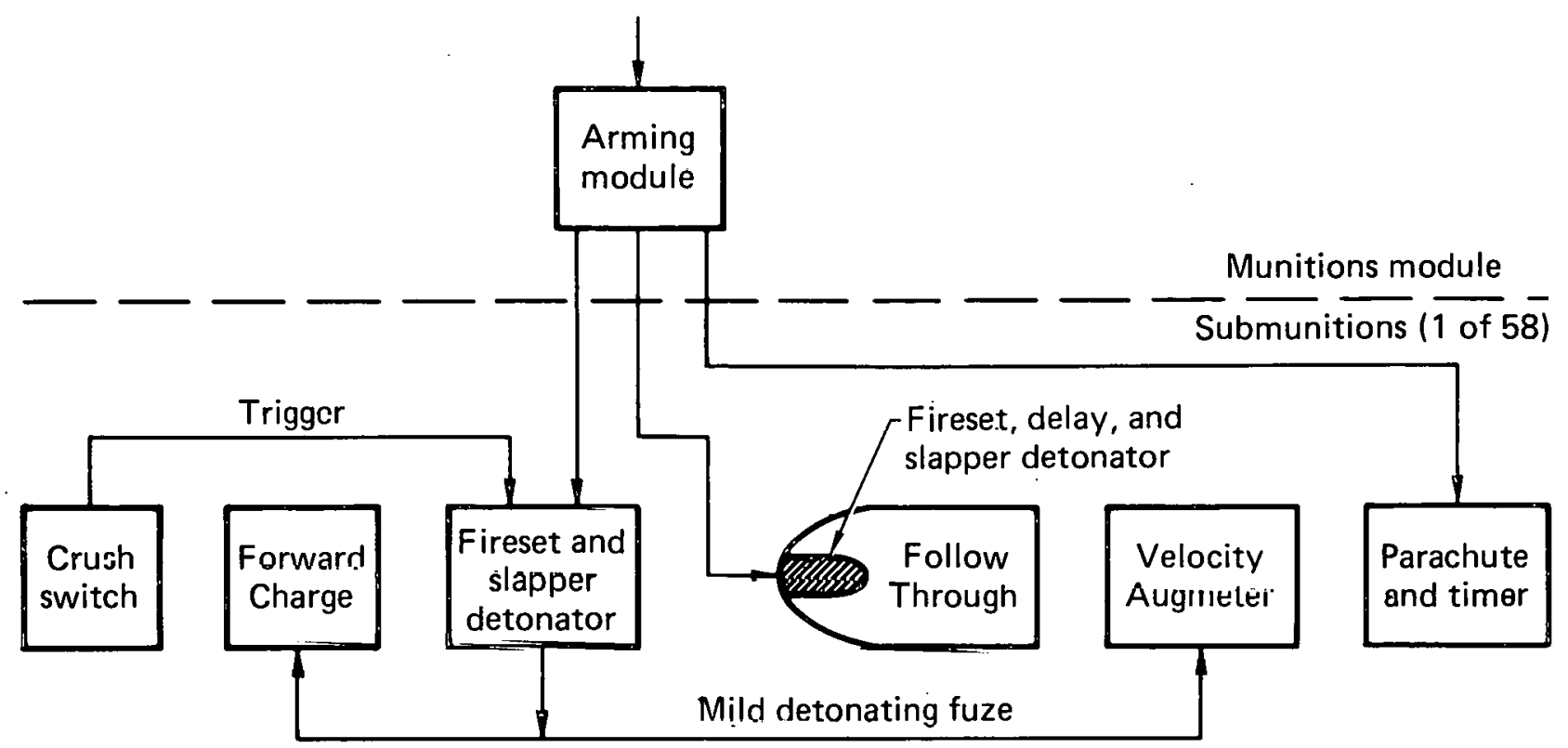

FIG. 1. The Tactical Airfield Attack Munition (TAAM) slapper detonator Safe Arming and Fuzing (SAF) system.

Fig. 2. The FT slapper detonator fuze is located in the nose of the FT case. The FT slapper detonator fuze consists of a $0.2-\mu \mathrm{F} 5-\mathrm{kV}$ timing oapacitor, a spark gap, timing resistors, velocity augmentor environment sensor switches and a slapper detonator with an LX-15 pellet.

The FT slapper detonator fuze is shown in Fig. 3. The operational sequence of the FT fuze starts by the arming module setting the short or long delay. The long delay is selected by passing current through a fusable link to enable a long time-constant resistor-capacitor network. The arming module via the $5-\mathrm{kV}$ dc-to-dc converter in the FC fireset cliarges the $0.2-\mu F$ energy storage capacitor to $5 \mathrm{kv}$. The arming module also charges the $0,05-\mu \mathrm{F}$ oapacitor to a voltage that determines the length of the selected delay. The fuze is disconnected and isolated from the dc-to-dc converter and the remainder of the external inputs upon experiencing the high shock from the velocity augmentor. At that point, the voltage on the timing capacitor begins to deray as the charge bleeds through a shunt resistor. The effective resistance value depends upon what delay time was selected short if the fusable link was not blown, or long if the fusable link was blown. When a point is reached where the trigger voltage reaches the threshold voltage for the spark gap, the charge on the $0.2-\mu F$ capacitor is switched to the slapper 
detonator to initiate the LX-15 (explosive) output pellet which in turn initiates the booster and the main charges.

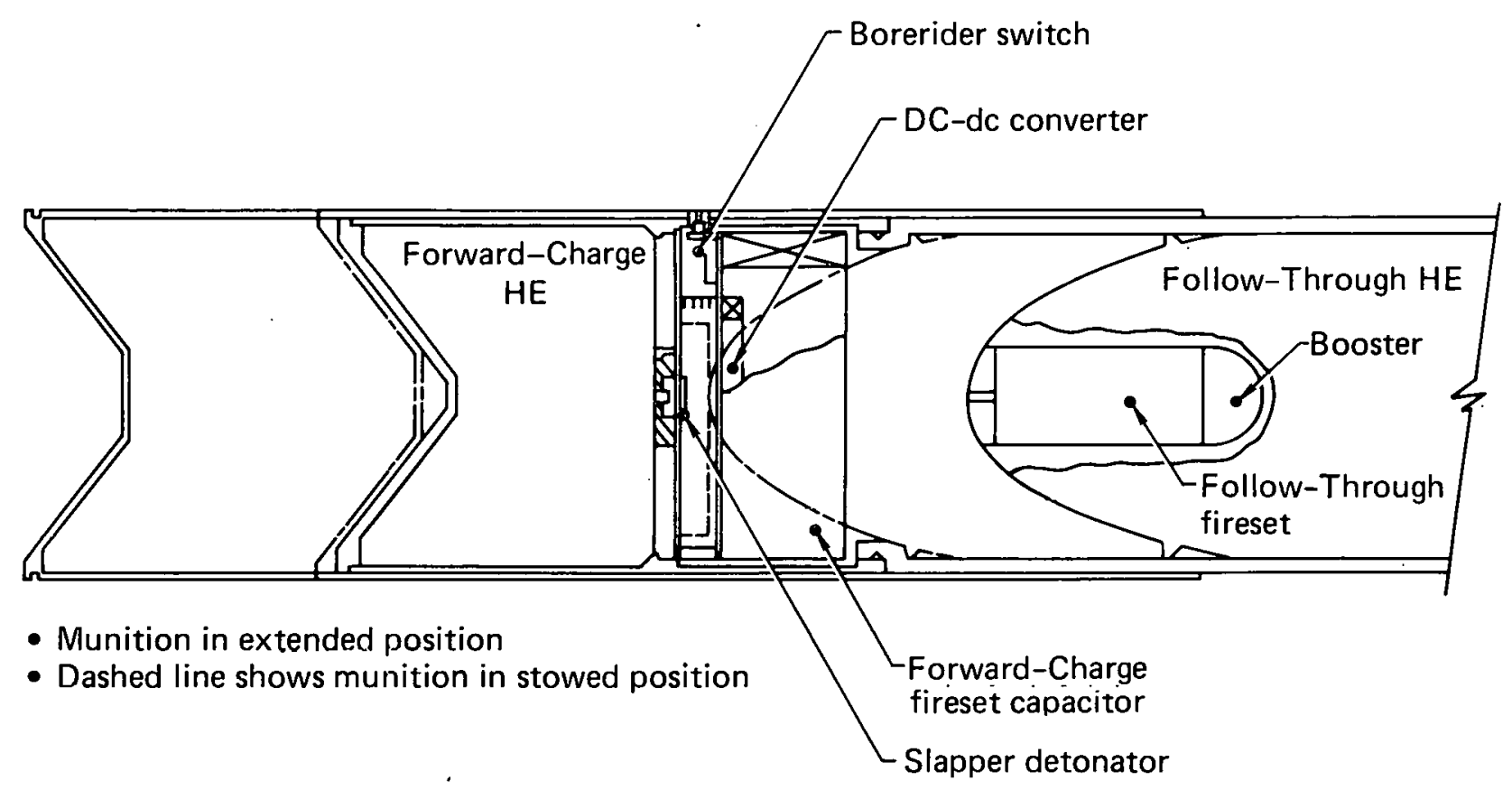

FIG. 2. The Velocity Augmented Munition-93 mm (VAM-93) in-line Safe Arming and Fuzing (SAF) system layout.

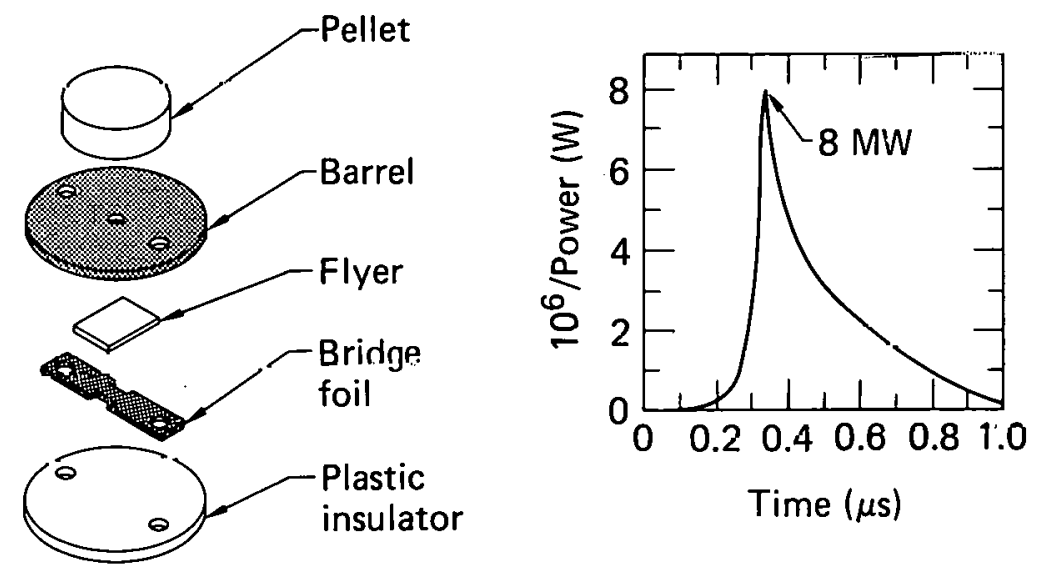

FIG. 3. Components of the slapper detonator.

$\mathrm{KW} / \mathrm{bp}$ 
Technical Information Department . Lawrence Livermore National Laboratory University of California · Livermore, California 94550

First Class Mail 